\title{
Strontium-90 in fish from the lakes of the Chernobyl Exclusion Zone
}

\author{
O.Ye. Kaglyan'1, D.I. Gudkov¹, V.G. Klenus", \\ Z.O. Shyroka ${ }^{1}$ and O.B. Nazarov ${ }^{2}$ \\ ${ }^{1}$ Institute of Hydrobiology of the NAS of Ukraine, Geroiv Stalingrada Ave. 12, \\ UA-04210 Kyiv, Ukraine \\ 2 "Chornobyl Radioecological Centre" of the Ministry of Emergency Situation of Ukraine, \\ Shkol'naya Str. 6, UA-07270 Chornobyl, Ukraine
}

\begin{abstract}
The radionuclide contamination of fishes from the Glubokoye and Dalekoye-1 Lakes (left-bank flood lands of the Pripyat River), Azbuchyn Lake and Yanovsky Crawl (right-bank flood lands of the Pripyat River), Pripyat River (near by Chernobyl town) and the main area of the Kyiv reservoir on a modern stage are explored and analyzed. The percentage of ${ }^{90} \mathrm{Sr}$ is shown in organs and fabrics of different fishes by the state on 2005-2007.
\end{abstract}

\section{INTRODUCTION}

After getting into water ecosystems, radionuclides enter into biogeochemical cycles and, being transferred through trophic chains, are accumulated by fish - one of the man's foodstuffs. This problem is especially important within the areas, which were highly contaminated with radionuclides as the result of the accident at the Chernobyl Nuclear Power Plant (ChNPP). Until now ${ }^{137} \mathrm{Cs}$ concentration prevailing over that of ${ }^{90} \mathrm{Sr}$ has been considered as a typical for radioecology of hydrobionts. However, ${ }^{90} \mathrm{Sr}$, being soluble and highly bioavailable, it began to play the predominant role in the lakes of the Chernobyl exclusion zone. Therefore, the main purpose of our paper was exploring radionuclide contamination of fish in lakes of the Chernobyl exclusion zone, especially with ${ }^{90} \mathrm{Sr}$.

\section{MATERIALS AND METHODS}

Lake Azbuchyn is located on the river Pripyat's right bank, and lakes Glubokoye and Dalekoye-1 on the left one at the distance of $2-5 \mathrm{~km}$ from the destroyed unit. During our investigations different ecological groups' representatives were analysed, namely: fishes-benthophages - silver crucian carp (Carassius auratus gibelio Bloch) 6-13 years old, common crucian carp (Carassius carassius L.) 5-6 years old, tench (Tinca tinca L.) 5-8 years old; fishes-ichthyophages - pike (Esox lucius L.) 3-5 years old, perch (Perca fluviatilis L.) 1-6 years old; and zooplanktophages - rudd (Scardinius erythrophthalmus L.) 1-5 years old, all of them being predominant fish species in lakes under study. Radionuclide concentration in fish was evaluated by radiochemical method according to oxalate technique with measuring by low background device. Radionuclides content (specific activity, concentration) in fish is given in Bq per $\mathrm{kg}$ at natural humidity.

\section{RESULTS AND CONCLUSIONS}

It has become conventional in water radioecology that ${ }^{137} \mathrm{Cs}$ is one of the basic dose-formed radionuclides in fish organism. Such pattern was registered during global fall-outs in result of the nuclear weapon test and in case of different local accident at nuclear power plants. In this respect fish 
in the Kyiv water reservoir, which is adjacent to the Chernobyl exclusion zone, were no exception (the average ratio ${ }^{90} \mathrm{Sr} /{ }^{137} \mathrm{Cs}=0.2$ ). Quite different pattern is observed in closed lakes of the exclusion zone, such as Glubokoye Lake, Azbuchyn Lake, Dalekoye-1 Lake. For example, the ${ }^{137}$ Cs concentration in fish tissues and organs being comparatively steady, since $1990 \mathrm{~s}$, the ${ }^{90} \mathrm{Sr}$ specific activity has been tending to increase in both pray fishes and predators. While in 1999 the ratio between ${ }^{90} \mathrm{Sr}$ and ${ }^{137} \mathrm{Cs}$ in benthophages was equal 0.2 , in $2000-0.6$, in 2001 it was already 2, and in 2006-2007 the average ${ }^{90} \mathrm{Sr}$ concentration exceeded ${ }^{137} \mathrm{Cs}$ in $2-5$ times. The ${ }^{90} \mathrm{Sr}$ concentration in water having increased twice for the period under study, the radionuclide concentration in fish has become 5-6 times as high as before [1]. Such dynamics in fish tissues of the river Pripyat's left-bank flood-plain is likely to be related to the radionuclide physical and chemical forms change in the soil within the catchment area. The left-bank flood-plain being one of the most contaminated areas, it was dammed in 1992-1993, which changed the stream conditions of the rivers and caused their swamping. In this connection, radionuclides are desorbed and washed out of the soils adjacent to water-bodies. ${ }^{90} \mathrm{Sr}$ forms soluble complexes with fulvous acids, these complexes enter the biotic cycle in water ecosystems, while ${ }^{137} \mathrm{Cs}$ is accumulated in the bottom sediments. This is confirmed by the increased ${ }^{90} \mathrm{Sr}$ concentration in the water of the lakes under investigation against the background of comparative ${ }^{137} \mathrm{Cs}$ stabilisation and raised ${ }^{90} \mathrm{Sr}$ level in higher aquatic plants in lakes Glubokoye and Dalekoye-1. ${ }^{90} \mathrm{Sr}$ concentration increase rate in predators' organisms is slower, and it slightly exceeded the total ${ }^{137} \mathrm{Cs}$ amount in individual predators as recently as last year. ${ }^{90} \mathrm{Sr}$ concentration in fish is shown in Table 1.

Table 1. ${ }^{90} \mathrm{Sr}$ average specific activity in fishes from the lakes under study of the Chernobyl exclusion zone and the Kyiv water reservoir upper reaches in 2006-2007, Bq/kg.

\begin{tabular}{|l|c|c|}
\hline Fish & Lake & ${ }^{90}$ Sr specific activity \\
\hline Common crucian carp & Azbuchyn & 9265 \\
\hline Tench & Azbuchyn & 4727 \\
\hline Common crucian carp & Glubokoye & 19208 \\
\hline Silver crucian carp & Glubokoye & 15879 \\
\hline Tench & Glubokoye & 8427 \\
\hline Rudd & Glubokoye & 16073 \\
\hline Perch & Glubokoye & 14656 \\
\hline Tench & Dalekoye-1 & 3202 \\
\hline Rudd & Dalekoye-1 & 7984 \\
\hline Perch & Dalekoye-1 & 3200 \\
\hline Pike & Dalekoye-1 & 2778 \\
\hline Silver crucian carp & Kyiv water reservoir & 5.3 \\
\hline Tench & Kyiv water reservoir & 3.7 \\
\hline Perch & Kyiv water reservoir & 3.6 \\
\hline Pike & Kyiv water reservoir & 1.9 \\
\hline
\end{tabular}

Our data have shown ${ }^{90} \mathrm{Sr}$ concentration to be maximal in fish scales and vary in crucian carp within 56581-83947 Bq/kg (Glubokoye Lake), 28600-42550 Bq/kg (Azbuchyn Lake), in rudd (Glubokoye Lake) - within 42898-64983 Bq/kg, in tench (Glubokoye Lake) - within 20542-26335 Bq/kg, in tench (Azbuchyn Lake) - within 13994-19038 Bq/kg, and in tench (Dalekoye-1 Lake) - 8964-13726 Bq/kg of raw weight. In predatory fish species radionuclide concentration varied within $55020-63259 \mathrm{~Bq} / \mathrm{kg}$ in perch (Glubokoye Lake) and $7512-12840 \mathrm{~Bq} / \mathrm{kg}$ in pike (Dalekoye-1 Lake). High level of ${ }^{90} \mathrm{Sr}$ specific activity was observed in fish bones: in the species of Carassius genus it reached 36000-89000 (Glubokoye Lake) and 22500 Bq/kg (Azbuchyn Lake); in tench - 27314-29173 (Glubokoye Lake) $11516-15346 \mathrm{~Bq} / \mathrm{kg}$ of raw weight (Azbuchyn Lake); in rudd ${ }^{90} \mathrm{Sr}$ concentration equalled $50000 \mathrm{~Bq} / \mathrm{kg}$. Specific activity of ${ }^{90} \mathrm{Sr}$ in fish muscles was comparatively low - 187-1580 (crucian carp, Glubokoye Lake), 77-240 (crucian carp, Azbuchyn Lake), 273-310 (tench, Glubokoye Lake), 304-374 (tench, Azbuchyn Lake) and 349-505 (rudd, Glubokoye Lake) Bq/kg of raw weight. ${ }^{90} \mathrm{Sr}$ concentration (specific activity), for example, in organs and tissues of Common crucian carp is shown in Fig. 1 


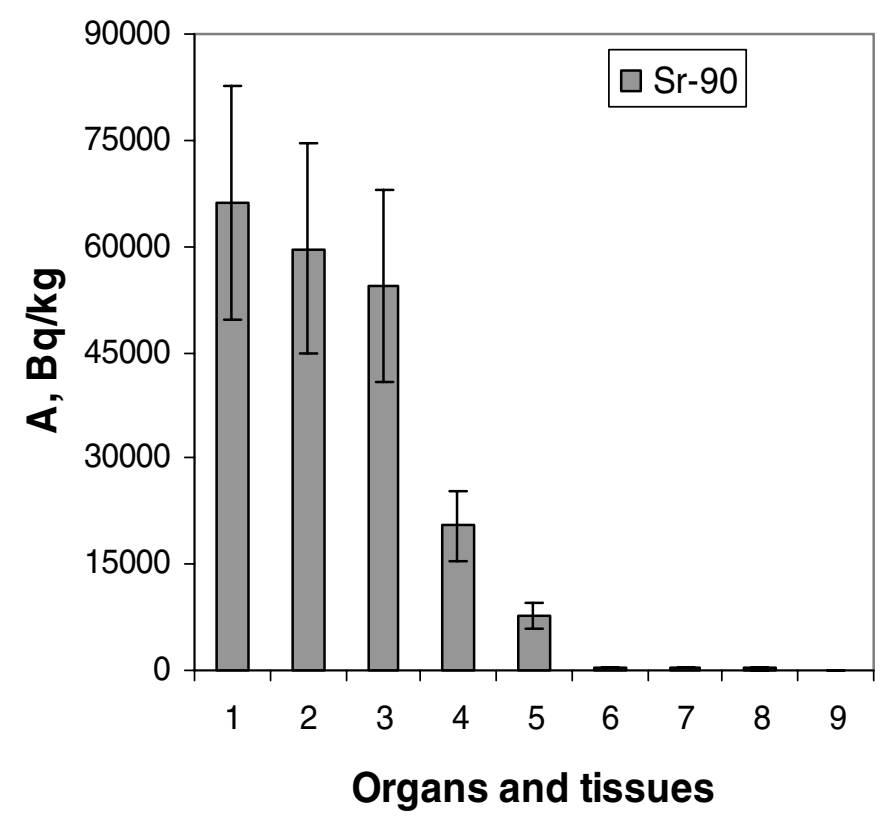

Figure 1. ${ }^{90} \mathrm{Sr}$ content (specific activity) in organs and tissues of Common crucian carp (Glubokoye Lake): 1 -scales; 2 - bones; 3 - fins; 4 - head; 5 -stomach contents; 6 - skin; 7 - muscles; 8 -internal organs; 9 -roe.

${ }^{90} \mathrm{Sr}$ specific activity in the fish of exclusion zone lakes decreases from fishes-zooplanktophages to fishes-benthophages. The lowest radionuclid concentration is observed in predatory species and such benthophages as tench. In the Kyiv water reservoir upper reaches fishes can be placed in such order according to the ${ }^{90} \mathrm{Sr}$ concentration diminishing: sabrefish (Pelecus cultratus L.) $>$ bream (Abramis brama L.) > silver crucian carp (Carassius auratus gibelio Bloch) $>$ roach (Rutilus rutilus L.) $>$ tench (Tinca tinca L.) > perch (Perca fluviatilis L.) > carplike fish (Aspius aspius L.) > catfish (Silurus glanis L.) > zander (Sander lucioperca L.) > pike (Esox lucius L.) [2].

As it can be seen in Figs. 2, 3 and 4 the main fish organs and tissues to accumulate ${ }^{90} \mathrm{Sr}$ are scales, bones, fins and head, that is calcium-containing organs. These organs and tissues, though making as little

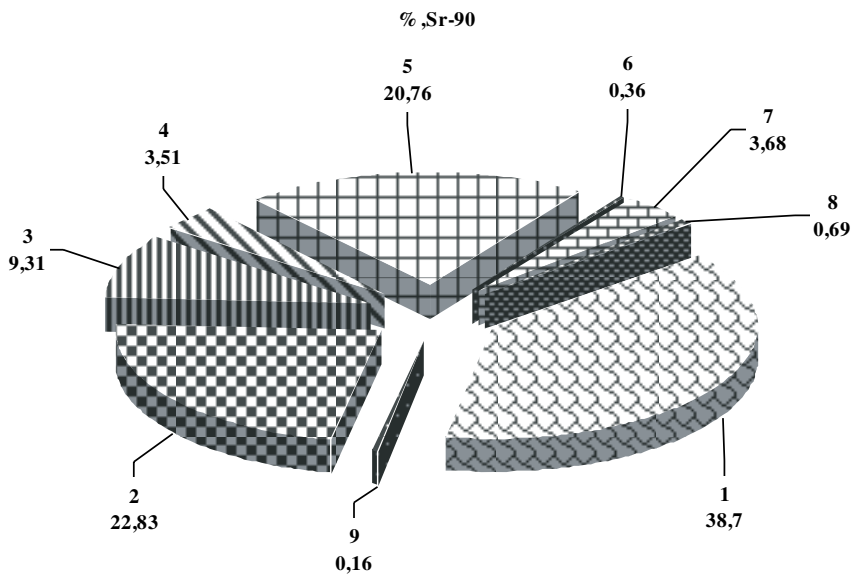

Figure 2. ${ }^{90} \mathrm{Sr}$ distribution in organs and tissues of crucian carp (Glubokoye Lake): 1 - scales; 2 - bones; 3 - fins; 4 - gills; 5 - head; 6 - stomach contents; 7 - muscles; 8 - internal organs; 9 - skin. 


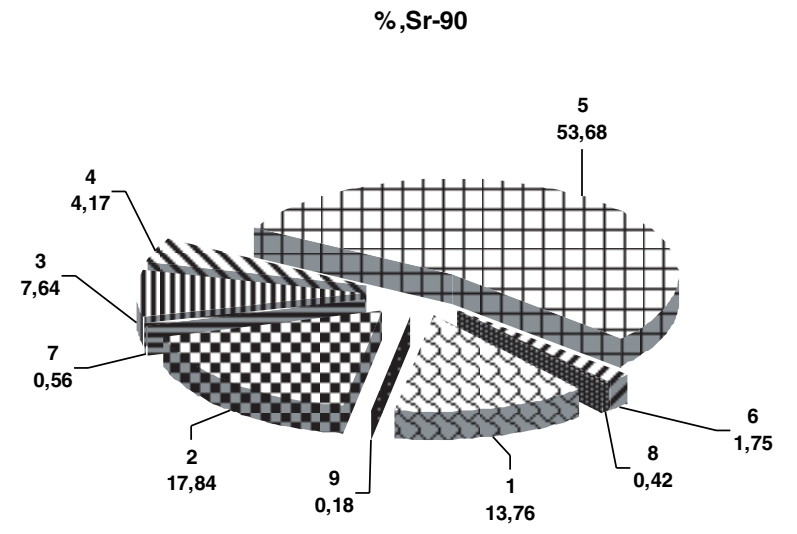

Figure 3. Radionuclide distribution in the organs and tissues of pike (Dalekoye-1 Lake): 1 - scales; 2 - bones; 3 - fins; 4 - gills; 5 - head; 6 - stomach contents; 7 - muscles; 8 -internal organs; 9 - skin.

\section{$\%, \operatorname{Sr}-90$}

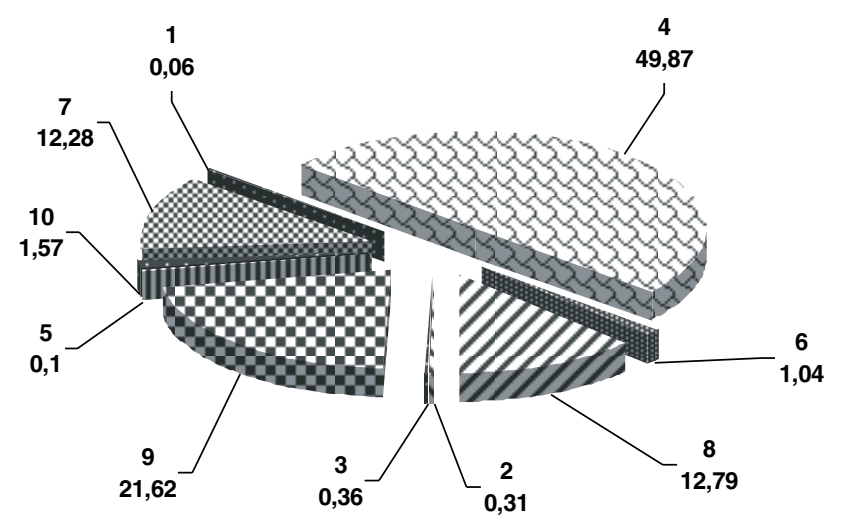

Figure 4. ${ }^{90} \mathrm{Sr}$ distribution in organs and tissues of rudd (Glubokoye Lake): 1 - internal organs; 2 - stomach contents; 3 - roe; 4 - scales; 5 - skin; 6 - muscles; 7 - fins; 8 - bones; 9 - head; 10 - gills.

as $23-37 \%$ of the total body weight, accumulate about $92-97 \%$ of the total ${ }^{90} \mathrm{Sr}$ in fish of the exclusion zone lakes. At the same time for the Kyiv water reservoir, this proportion equals $69-84 \%$. This fact can be possibly explained by the radionuclide sorption on fish surface in lakes highly polluted with ${ }^{90} \mathrm{Sr}$.

The data analysis has shown the predatory fish of the exclusion zone close lakes to accumulate ${ }^{90} \mathrm{Sr}$ mainly in the head (31.9-53.7\%), scales (13.8-36.3\%) and bones (11.0-17.8\%). Such benthophages as Carassius accumulate the radionuclide in descending order: scales $(34.0-38.7 \%)>$ bones $(22.8-24.2 \%)>$ head (20.7-24.0\%), and zooplanktophages (rudd) - scales (42.4-51.6\%) > head (21.6$25.4 \%)>$ bones $(12.6-13.5 \%)$. The muscles of ichthyophages contain $0.6-0.9 \%$ of ${ }^{90} \mathrm{Sr}$, and those of benthophages and zooplanktophages $-1.0-3.7 \%$.

Thus, in the exclusion zone isolated lakes a strong tendency of ${ }^{90} \mathrm{Sr}$ increase in the tissues of fish, belonging to different ecological groups has been observed. This is likely to be related to the rise of radionuclide mobile forms level in the soils of catchment area and its washing-out to the lakes. The radionuclides distribution in the organs and tissues of fish from the exclusion zone flood-plain lakes having been analyzed, $92-97 \%$ of ${ }^{90} \mathrm{Sr}$ to be accumulated in fish bones and scales, and only $0.6-3.7 \%$ in muscles. ${ }^{137} \mathrm{Cs}$ concentration in fish tissues and organs being comparatively steady, since 1990 s the 
${ }^{90} \mathrm{Sr}$ specific activity has been tending to increase in both prey and predatory fish. Therefore, nowadays ${ }^{90} \mathrm{Sr}$ is the basic dose-forming radionuclide for fish of close water bodies within the exclusion zone.

\section{Acknowledgments}

The authors wish to thank the personnel of Fresh-water Radioecology Department of Institute of hydrobiology of the NAS of Ukraine.

\section{References}

[1] Gudkov, D.I. et al., Radiation biology. Radioecology, 1 (2008), pp. 48-58 (Rus).

[2] Kaglyan, O.Ye. Hydrobiological journal, 5 (2007), pp. 93-109 (Rus). 
